Soroka I.A. assistant professor, candidate of psychological sciences, "Law Institute "KNEU named after Vadym Hetman"

\title{
CONTINUING PROFESSIONAL DEVELOPMENT OF TEACHERS OF ENGLISH: IMPORTANCE AND PECULIARITIES
}

The purpose of this article is to introduce the scholars' views on the topic of Continuing Professional Development (CPD) and its various forms. The researchers came to the conclusion that there is a need for universities to develop and implement a Continuing Professional Development policy for teachers of English in Ukraine. This work presents the stages of teacher development (awareness, understanding, engagement, integration) and reasons (recognition, imposition, self-improvement, enjoyment) for carrying out CPD. Scientific literature compares traditional professional development activities (workshops, seminars, conferences) to non-traditional ones (mentoring, coaching, peer observation etc.). The results of the research which consisted of different forms (interviews, a workshop) are discussed. The ways of creating a unique selling point (USP) and the forms of professional development portfolio, which will help teachers of English to promote themselves, are introduced in this paper. Ten tips on how to develop English teachers' USP are presented in the article. Key words: CPD, professional development portfolio.

Сорока І.А. Безперервний професійний розвиток викладачів англійської мови: важливість та особливості. Мета цієї статmі - представити погляди вчених щодо важливості безперервного професійного розвитку, різні форми та описати його особливості для викладачів англійської мови. У статті обговорюються результати дослідження та представлено фрорми портфоліо профресійного розвитку викладачів англійської мови.

Ключові слова: безперервний профресійний розвиток, портфроліо профресійного розвитку.

Сорока И.А. Непрерывное профессиональное развитие преподавателей английского языка: важность и особенности. Цель этой статьи - представить взгляды ученых о важности непрерывного профрессионального развития, различные формы и описать его особенности для преподавателей английского языка. В статье обсуждаются результаты исследования и представлены фрормы портфолио профрессионального развития преподавателей английского языка.

Ключевые слова: беспрерывное профессиональное развитие, портфолио профрессионального развития.

\section{Introduction}

With the implementation of the education reforms in Ukraine the issue of Continuing Professional Development (CPD) has become a burning issue. It is widely known that every five years teachers have to upgrade qualification. For most teaching staff this procedure has become an unpleasant burden as not all forms of training were accepted. Hopefully the situation will change and teachers will get a really practical training designed for their professional needs. Learning doesn't stop when a teacher leaves college or university or obtains initial ELT 
(English language teaching) qualifications. Lifelong learning means a process of learning or reflective practice that continues throughout a professional life. Such learning can be done formally or informally and can occur on a regular or infrequent basis.

CPD comes in many different forms and some of the most common include conference attendance, reading articles and peer observation or studying for a higher qualification such as the DELTA. For CPD to have impact, it should be innovative, memorable, practical, convincing, hands-on, informative and motivating $[5,1]$.

Teachers (especially linguists) have to take into consideration that modern generation, called by some researchers "net generation", spends a lot of time playing computer games. The Internet, gadgets, video games have become an integral part of the youth; hence teaching methods should be adjusted to the needs and interests of teenagers and young people to motivate and help them in studying.

New applications, which help learners to study languages, appear almost every day, so modern teachers have to not only know about them, but try to use those in their work. There are a lot of opportunities for Ukrainian students to study abroad which leads to the increasing demand for the contemporary English language.

\section{Objectives}

The purpose of this article is to introduce the scholars' views on the topic of CPD, its various forms and opportunities for teachers of English.

\section{Literature review}

Different authors (teachers) have expressed their opinions on professional development [5,1]: "Feeling good about yourself is your top professional responsibility", Susan Barduhn; "We cannot be developed; development is something we do to ourselves", Jenny Johnson; "Teacher development is the process of becoming the best teacher one is able to be, a process that can be started but never finished", Adrian Underhill; [CPD is the difference between] 'teachers with 20 years' experience and those with one year's experience repeated 20 times", Penny Ur.

Y. Cheng [3] stated that high quality teachers are important for the enhancement of quality of education. T. Guskey noted "we cannot improve schools without improving the skills and abilities of the teachers within them" $[8,9]$.

The stages of development are introduced in Frameworks for teachers [6]. Stages of development:

1. Awareness (you have heard of this professional practice).

2. Understanding (you know what the professional practice means and why it's important).

3. Engagement (you demonstrate competency in this professional practice at work).

4. Integration (you demonstrate a high level of competency in this professional practice and this consistently informs what you do at work).

According to $\mathrm{D}$. Foord [7] reasons for carrying out CPD can be described using 
the acronym RISE - Recognition, Imposition, Self-improvement, Enjoyment.

Recognition might come from financial reward, professional status or from colleagues.

Imposition: the need to complete a formal qualification may be imposed on you by your employer.

Self-improvement: by improving your skills and knowledge you increase your feeling of self-worth.

Enjoyment: you may simply enjoy undertaking certain forms of development.

L. Starkey [11], M. Rogers et al. [10] argue that professional development programmes are necessary not only for newly qualified teachers but also for experienced ones. Professional development programmes are important for self-renewal, developing existing skills and acquiring new ones.

Scholars differentiate traditional and non-traditional professional development activities. International scientific literature compares traditional professional development activities (workshops, seminars, conferences etc.) to nontraditional ones (mentoring, coaching, peer observation etc.). The choice of a different type may depend on the duration of a professional development programme, teachers' needs, context etc. [1].

\section{Methods}

Various methods were used in this research. A three-hour workshop "Continuing professional development for teachers of English" was developed as a part of a Teacher Professional Development Summer School for teachers of English, organised in collaboration of the British Council and IATEFL Ukraine (International Association of Teachers of English as a Foreign Language). Participants: a group of 15 teachers of English from different cities of Ukraine aged from 23 to 55 . On-line and face to face interviews, which involved 30 more teachers of English, were also conducted as the part of this research.

\section{Results and discussions}

The results of the research show that the teachers of English, who took part in various activities mentioned above, are aware of the importance of continuing professional development. The most popular forms of CPD notified by the participants during the workshop and interviews are the following: participating in trainings and conferences, post graduate study, publications (articles, course books etc.), teachers exchange and internship.

It is vital to create and enrich a professional development portfolio [5].

A professional development portfolio can take different forms:

- folder containing hand-written learner diary, pictures, photos, copies of articles and presentation slides, lesson plans;

- electronic files including the above, PowerPoint slides, scanned certificates, audio and video files, links to websites;

- webpage, blog, about me page.

The results of the surveys show that the most frequently used forms by Ukrainian teachers of English are electronic files (audio, video, books), links to websites. Some teachers are thinking of creating professional blogs.

The professional development portfolio can contain formal documents as well as samples of the materials a teacher created, feedback from supervisors, 
mentors or peers etc.

It is also very important to think about the teacher's USP. A unique selling point (USP) refers to what makes a "product" (in our case a teacher) different from, and better than what is already available on the market $[5,17]$. In ESP teaching, for instance, it is useful to develop teaching skills in a particular field - finance, law etc. Creating a USP will help to promote yourself as a teacher; either when applying for a new job or seeking promotion in your current place of work. The decision to create a USP will also help guide CPD - in choice of activities, and knowing what to include in professional portfolio.

The USP of the teachers who took part in our research included: knowledge of two or more foreign languages, $\mathrm{PhD}$ in philology, pedagogic or psychology; some teachers have a second education (engineering, for instance). The majority of the university teachers are the authors of course books. Some participants have taken a special course and obtained CELTA (Certificate in English Language Teaching to Adults). One of the trainees won a grant and studied abroad. All of these examples are great USP, which promote them as outstanding teachers.

However, the situation is different across the country. From 2014 up to 2017 in partnership with the Ministry of Education and Science of Ukraine, the British Council conducted in-depth studies of 15 Ukrainian universities to evaluate the current role and status of the English language. The researchers came to the conclusion that there is a need for universities to develop and implement a Continuing Professional Development policy for teachers of English with a requirement for regular updates in teaching methodology [2].

In the research conducted by the British Council the teachers of English were tested, using the British Council's Aptis test, which provides results aligned to the CEFR (Common European Framework of Reference for Languages). The results demonstrated that, while a majority (61 per cent) of those tested reached level C, a significant proportion (39 per cent) did not and a few (4 per cent) were assessed at only B1 or A2 levels. This weakness is likely to affect the quality of the English teaching in Ukrainian universities [2, 32]. Consequently continuing professional development of teachers of English stays the problematic issue in our country.

The scholars introduce ten tips on how to develop teachers' USP $[5,18]$.

1. Ask a content specialist (subject lecturer at institution, peer, former student) to become your mentor or provide guidance and advice on an occasional basis.

2. Attend subject content classes at your institution.

3. Work through some of the key texts on your learner's recommended reading list.

4. Become a member of a community of practice in the subject area (Linkedln, Facebook groups, online forums, special interest groups of a national and international teaching association).

5 . Set up your own community of practice (for ESP teachers) in your specific field.

6. Invest in research materials to become better acquainted with the subject matter (benefit from second hand books on Amazon).

7. Subscribe to a specialised (online) magazine. 


\begin{abstract}
8. Watch presentations in the specialist area on TED Talks or similar. free).

9. Attend conferences in the specialist area (online conferences may be

10. Participate in workshops organised by special interest groups.

Modern teachers have a lot of opportunities to develop (not only in big cities). The British Council Ukraine organized various trainings for ESP (English for specific purposes) teachers free of charge in a project "English for Universities". At the site of the British Council (http://www.teachingenglish.org.uk) teachers can find various activities, materials (for different age category), announcements about events and courses. This organisation also provides free online courses for teachers of English.
\end{abstract}

On the site https://busyteacher.org/ there is a wide choice of articles, books and lesson materials for various topics. It is a good idea for teachers of English to share books, experience, materials and inform colleagues about useful websites as well as different events: conferences, courses, competitions etc.

At annual IATEFL (http://ukraineiatefl.wixsite.com/iateflukraine) conferences Ukrainian teachers and guests from abroad present new activities, programmes, methods of ELT. Teachers can participate in such conferences around the world (in Poland, Hungary, Malta etc.) or compete for the grant to take part in IATEFL conference in Great Britain. This Association of Teachers of English regularly organises winter and summer schools as well.

Other opportunities include taking certification IELTS or TKT courses, studying at Cambridge CELTA / DELTA Courses, visit seminars and workshops, organised by International Language Centre (ILC) or Cambridge University Press ELT Ukraine. America house provides various cultural and educational events as well (speaking club, American literature club, English movie night, exhibitions), which can be helpful and practical both for students and their teachers. These are only some examples and advice how teachers of English can continue professional development.

\title{
Conclusion
}

The scholars' views on the topic of CPD and its various forms were introduced in this article. Different ways of professional development were discussed here, including: collaborating with colleagues and other professionals, doing research, attending and presenting at conferences, participating in trainings, reading and publishing, joining teachers' associations, observing other teachers and being observed.

The article presented various forms of professional development portfolio. Unique selling points of the participants of the research were identified during the workshop and the tips how to develop USP of teachers of English were discussed.

To sum up, it is necessary to mention that though the buzz term "lifelong learning" is not new in the scientific literature and education, it hasn't lost its importance. Teachers stay maybe the first in the list of specialists, who should update their skills and knowledge nonstop. 


\section{References}

1. Bayar, A. (2014). The Components of Effective Professional Development. Activities in terms of Teachers' Perspective. International Online Journal of Educational Sciences, 6 (2), pp. 319327. Retrieved from https://files.eric.ed.gov/fulltext/ED552871.pdf

2. Bolitho, R., West, R. (2017). The internationalisation of Ukrainian universities: the English language dimension, K. ISBN-978-617-676-123-5 - $134 \mathrm{p}$.

3. Cheng, Y. C. (1996). Relation between teachers' professionalism and job attitudes, educational outcomes, and organizational factors. The Journal of Educational Research, 89 (3), pp.163171.

4. Continuing professional development. The free dictionary. Retrieved from http://encyclopedia. thefreedictionary.com/Continuing+Professional+Development

5. Certificate in Vocational English Language Teaching (2013). Module 30 - Continuing professional development in vocational education. British Council., 30 p.

6. Continuing Professional Development (2015). Framework for teachers. British Council, 20 p.

7. Foord, D. (2009). The developing teacher: Practical activities for professional development Country Peaslake, United Kingdom: Delta Publishing, 250 p.

8. Guskey, T. (2002). Professional development and teacher change. Teachers and Teaching: theory and practice, 8(3). DOI: 10.1080/135406002100000512

9. Linnemanstons, K., Jordan, C. (2017). Learning through place: Evaluation of a professional development program for understanding the impact of place-based education and teacher continuing education needs. Journal of Sustainability Education, Vol. 12, February. Retrieved fromhttp://susted.com/RATS_2.3/UploadsFinalPDFs/1983_201725\%2022.34.42 Linnemanstons\%20JSE\%20February\%202017\%20General\%20Issue\%20PDF\%20Ready. pdf

10. Rogers, M., Abell, S., Lannin, J., Wang C-Y., Musikul, K., Barker, D., Dingman, S. (2007). Effective professional development in science and mathematics education: Teachers' and facilitators' views.International Journal of Science and Mathematics Education, 5, pp. 507532. DOI: $10.1007 / \mathrm{s} 10763-006-9053-8$

11. Starkey, L., Yates, L., Meyer, C., Hall, C., Taylor, M., Stevens, C. \& Toia, R. (2009). Professional development design: Embedding educational reform in New Zealand. Teaching and Teacher Education, 25, - pp.181-189. DOI: 10.1016/j.tate.2008.08.007

Стаття надійшла до редакції 17.03.2018 p. 